\title{
THE ROLE OF IMPORT FOR KIBS INTENSITY: A COMPARATIVE ANALYSIS OF EUROPEAN UNION COUNTRIES
}

\author{
JOANNA WYSZKOWSKA-KUNA \\ University of Łodź, Department of World Economy and European Integration, POLAND \\ e-mail: jkuna@uni.lodz.pl
}

RECEIVED
ACCEPTED
JEL
CLASSIFICATION

KEYWORDS knowledge-intensive business services, KIBS, EU, import, trade in services

ABSTRACT The aim of this paper is to study the role of import for the growth of KIBS intensity in the economy. The study covers the EU countries, making it possible to carry out a comparative analysis between countries, in particular between the EU-15 and the EU-12. The study is based on the data from the World Input-Output Database (WIOD). Owing to the availability of relevant data, the period analysed covers the years 1995-2011.

The study demonstrates that KIBS intensity is higher in the more developed EU countries, and KIBS are mainly delivered from domestic markets. Exceptions include Ireland and Luxembourg, distinguished by the highest and rapidly growing KIBS intensity (satisfied mainly by import), which is accompanied by their strongest KIBS export performance. In the analysed period, the importance of imported KIBS increased (mainly in the EU-15), but to a much lesser degree than with respect to manufacturing products. The role of imported KIBS was higher in the EU-12 than the EU-15 (with a trend to decrease these disparities), as well as in smaller economies.

\section{Introduction}

The development of knowledge-based economy, the information and communications technology (ICT) revolution, and increased competition on markets have resulted in the need to reorganize production processes in enterprises so that they can effectively exploit the intellectual potential of more educated workers, supported by ICTs and automation (Bhagwati, 1984; Jones, Kierzkowski, 1990; Motohashi, 1997; Fixler, Siegel, 1999; Baldwin, 
$2006,2014)$. These changes have led to (1) the growing fragmentation of production; and (2) the growing demand for business services, in particular those related to new technologies and knowledge, which are called 'knowledgeintensive business services' (KIBS).

The existing literature demonstrates that companies using KIBS improve their competitiveness (a review of the literature in this field can be found in Wyszkowska-Kuna, 2016), and the level of intermediate consumption of KIBS within a domestic economy improves the competitiveness of its KIBS sector (Wyszkowska-Kuna, 2016, 2017). The goal of this paper is to examine KIBS intensity and the role of import in delivering KIBS to EU companies.

The study also tries to answer the question regarding the impact of market size and the level of economic development on KIBS trade. In the light of international trade theory, KIBS imports should play a more important role in smaller economies (as they tend to be more trade-dependent than larger ones), as well as in less developed countries (as they tend to be worse endowed with knowledge than more developed ones). One should note, however, that trade in intermediates depends less on a country's market size, which represents a chance for smaller and emerging economies (Miroudot, Lanz, Ragoussis, 2009).

\section{Global sourcing of KIBS}

The dynamic development of global sourcing is linked to the ICT revolution. The rapidly declining costs of communication and coordination have made it possible to perform most manufacturing stages in different locations (Baldwin, 2006, 2014). Most recently, the ICT revolution has increased significantly the tradability of many services, and then the process has spread from factories to offices (Baldwin, Lopez-Gonzalez, 2015). This, in turn, has stimulated the development of international trade in intermediates with respect to both manufacturing goods and services.

Over the recent years the range of business services that have been subject to global sourcing has not only grown, but has also changed its structure. The growing demand for specialized business services has reduced the importance of simple, routine and standardized tasks, while increasing the role of processes with higher value added (Lewin, Massini, Peeters, 2009). It should be noted, however, that the possibility of providing services from a distance is primarily applicable to highly standardized services (Rybiński, 2008). Tailor-made services, produced in interaction with clients - and a large part of KIBS can be considered as such - require direct contact between service suppliers and recipients. In this case, international production through foreign direct investment seems to be a better way of internationalisation. On the other hand, the technological progress in ICTs is constantly creating better and cheaper communication between service providers and their clients, which together with the ease of travel should have a positive impact on the possibility of distant deliveries, including with respect to KIBS. As a result, the issue becomes of the extent to which they are provided by companies operating on domestic markets, and the extent to which they are traded internationally.

\section{Data and pesearch methodology}

The study is based on input-output tables from the WIOD database (National Input-Output..., 2013) showing the structure of domestic and imported intermediate inputs in each of the EU countries. To compare the results for groups known as the EU-15 and EU-12, weighted averages for them are calculated. Data showing the structure of domestic and imported intermediate inputs is available for divisions according to NACE Rev. 1.1 for the period 
1995-2011. In the light of available data, KIBS can be defined as comprising 'Renting of Machinery \& Equipment and Other Business Activities' (divisions 71-74).

Two main indicators are used in the study. The first indicator examines the role of import in providing EU companies with KIBS input, and it takes the form of the share of imported KIBS input in total (domestic and imported) KIBS input (i.e. $\frac{\sum_{\mathrm{j}} \mathrm{KIBS}_{\mathrm{jit}}^{\mathrm{mm}}}{\sum_{\mathrm{j}} \mathrm{KIBS}_{\mathrm{jit}}^{\mathrm{T}}}$, where $\mathrm{j}$ is the industry, $i$ the country, $t$ time, Im imported, and $T$ total). The second indicator, in the form of the ratio of total or imported KIBS input and GDP (i.e. $\frac{\sum_{j} K_{j} S_{j i t}^{D}+\sum_{j} K I_{\text {inS }}^{I m}}{\sum_{j} G D P_{j i t}}$

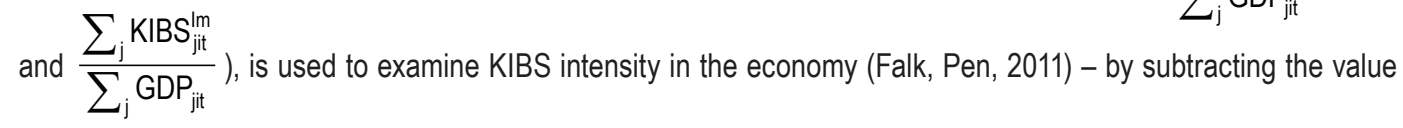
of imported from total KIBS intensity one can obtain the value of domestic KIBS intensity. Additionally, the second

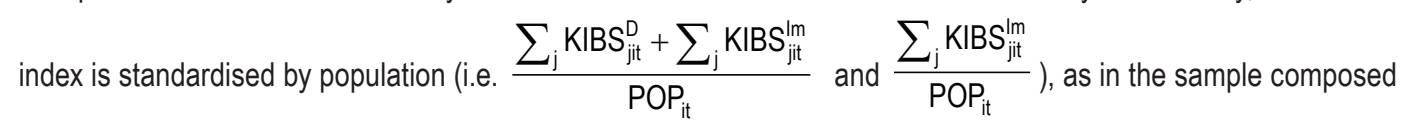
of countries being at different levels of economic development, the number of population should better control for size effects than the value of GDP.

In order to characterize countries with different imported KIBS intensities, the indicators measuring the role of (1) KIBS exports (i.e. $\frac{\text { EXP }_{\text {KIBSit }}}{\sum_{j} E_{\text {jit }}}$ - the share of KIBS exports in total exports; $\frac{\text { EXP }_{\text {KIBSit }}}{\text { POP }_{\text {it }}}-$ KIBS exports per capita); and (2) foreign controlled enterprises (FCEs) in KIBS trade (i.e. $\frac{\text { EXP }_{\mathrm{KLBSit}}^{\mathrm{FCE}}}{\mathrm{EXP}_{\mathrm{KIBSit}}^{\top}}$ and $\frac{\mathrm{IMP}_{\mathrm{KBSSit}}^{\mathrm{FCE}}}{\mathrm{IMP}_{\mathrm{KIBSit}}^{\top}}$, where $T$ means total
enterprises) are included in the analysis.

\section{Empirical study}

Figure 1 shows the EU-27 average structure of KIBS input, taking into account the share of domestic and imported KIBS inputs, as compared with a similar structure for: a) services input; b) manufacturing input; and c) total intermediate inputs. Import plays much a more important role in delivering manufacturing input than services input to EU companies. In 1995, 34\% of manufacturing input and only 8\% of services input came from import, and in 2011 these disparities were further increased.

While, the growing role of import is visible with respect to both manufacturing and services inputs (including KIBS), the growth was significantly stronger in the case of manufacturing (13 percentage points (pp) compared to $3 p p$ for services). As a result, in 2011 on average almost half of manufacturing input (ranging from $87.6 \%$ in Luxembourg to $31.8 \%$ in Italy) came from import, while only $11 \%$ of services input (ranging from $60.7 \%$ in Luxembourg to $6.5 \%$ in France) came from import. The importance of import was slightly higher with respect to KIBS input in comparison to overall services input, and also showed an upward tendency.

In Table 1 the values of indicators measuring KIBS intensity and the role of imported KIBS input in the EU countries in 2011, as well as their changes between 1995 and 2011, are presented. 


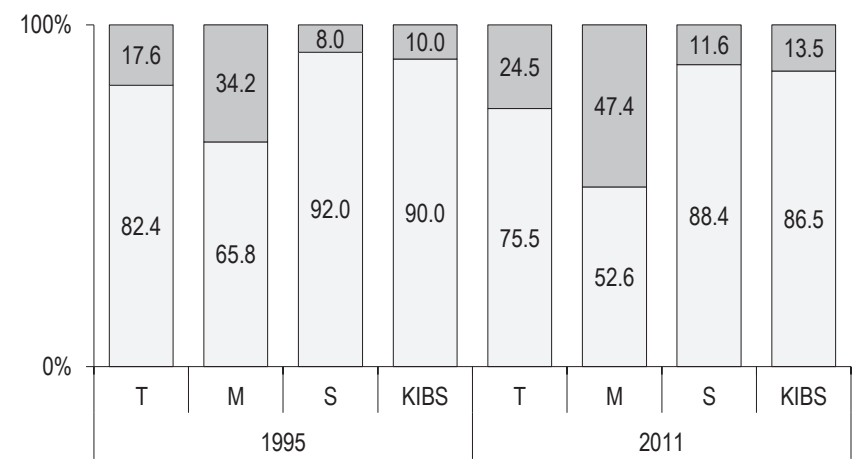

$\square$ Imported $\square$ Domestic

T - in total economy; M - in the manufacturing sector; S - in the service sector; KIBS - in the KIBS sub-sector.

Figure 1. Imported and domestic KIBS input in the EU countries ${ }^{1}$ in 1995 and 2011

Source: own calculations based on data derived from: National Input-Output... (2013).

Table 1. KIBS input in the EU countries

\begin{tabular}{|c|c|c|c|c|c|c|c|c|c|c|}
\hline \multirow{3}{*}{ Country } & \multicolumn{4}{|c|}{ KIBS input/GDP } & \multicolumn{4}{|c|}{ KIBS input per capita } & \multirow{2}{*}{\multicolumn{2}{|c|}{$\begin{array}{l}\text { Imported KIBS input/ } \\
\text { total KIBS input }\end{array}$}} \\
\hline & total & IMP & total & IMP & total & IMP & total & IMP & & \\
\hline & \multicolumn{2}{|c|}{$\begin{array}{l}2011 \\
(\%)\end{array}$} & \multicolumn{2}{|c|}{$\begin{array}{l}1995-2011^{*} \\
\text { (pp) }\end{array}$} & \multicolumn{2}{|c|}{$\begin{array}{c}2011 \\
\text { (mln of US\$) }\end{array}$} & \multicolumn{2}{|c|}{$\begin{array}{c}\text { 1995-2011* } \\
\text { (in mln of US\$) }\end{array}$} & $\begin{array}{l}2011 \\
(\%)\end{array}$ & $\begin{array}{c}1995-2011^{\star} \\
\text { (pp) }\end{array}$ \\
\hline 1 & 2 & 3 & 4 & 5 & 6 & 7 & 8 & 9 & 10 & 11 \\
\hline AUT & 6.5 & 1.1 & 2.1 & -0.2 & 6.2 & 1.0 & 4.1 & 0.4 & 16.4 & -12.8 \\
\hline BEL & 10.5 & 1.9 & 2.9 & 0.9 & 10.5 & 1.9 & 6.3 & 1.3 & 17.8 & 4.2 \\
\hline DNK & 8.6 & 1.2 & 4.0 & 1.0 & 9.3 & 1.3 & 6.6 & 1.2 & 14.2 & 9.0 \\
\hline FIN & 7.1 & 2.4 & 3.1 & 1.3 & 7.0 & 2.3 & 5.1 & 1.8 & 33.3 & 5.2 \\
\hline FRA & 10.7 & 0.7 & 1.5 & 0.3 & 8.3 & 0.5 & 4.1 & 0.3 & 6.6 & 2.0 \\
\hline DEU & 8.4 & 0.5 & 1.7 & 0.3 & 7.0 & 0.4 & 3.5 & 0.3 & 6.2 & 3.3 \\
\hline GBR & 10.7 & 1.0 & 5.1 & 0.4 & 7.4 & 0.7 & 5.3 & 0.4 & 9.0 & -1.9 \\
\hline GRC & 3.6 & 0.4 & -0.1 & 0.3 & 1.4 & 0.2 & 0.7 & 0.1 & 10.8 & 7.7 \\
\hline $\mathrm{IRL}$ & 15.1 & 11.5 & 9.1 & 8.2 & 15.4 & 11.8 & 13.2 & 10.5 & 76.3 & 21.0 \\
\hline ITA & 7.2 & 0.6 & 2.1 & 0.3 & 5.2 & 0.4 & 3.3 & 0.3 & 8.2 & 2.3 \\
\hline LUX & 11.0 & 6.7 & 4.6 & 3.7 & 33.9 & 20.7 & 27.9 & 17.8 & 61.0 & 13.8 \\
\hline NLD & 8.9 & 3.4 & 1.0 & 0.5 & 8.9 & 3.4 & 4.9 & 2.0 & 38.4 & 2.2 \\
\hline PRT & 6.6 & 0.7 & 1.6 & -0.1 & 2.7 & 0.3 & 1.7 & 0.1 & 10.0 & -5.7 \\
\hline ESP & 5.6 & 1.0 & 1.7 & 0.6 & 3.5 & 0.6 & 2.4 & 0.5 & 17.9 & 6.6 \\
\hline SWE & 9.1 & 2.3 & 3.4 & 1.0 & 9.9 & 2.5 & 6.9 & 1.8 & 25.2 & 2.9 \\
\hline BGR & 1.9 & 0.5 & 0.8 & 0.2 & 0.3 & 0.1 & 0.3 & 0.1 & 25.9 & 1.9 \\
\hline CYP & 4.6 & 0.3 & 1.2 & 0.0 & 2.1 & 0.1 & 1.4 & 0.1 & 6.3 & -3.7 \\
\hline CZE & 6.9 & 1.4 & 2.8 & 0.4 & 3.5 & 0.7 & 2.9 & 0.6 & 20.7 & -4.1 \\
\hline EST & 7.1 & 1.3 & 3.7 & 0.4 & 2.3 & 0.4 & 2.1 & 0.4 & 18.1 & -9.3 \\
\hline HUN & 6.6 & 2.5 & -0.1 & -0.2 & 2.1 & 0.8 & 1.5 & 0.6 & 38.1 & -2.1 \\
\hline LVA & 6.2 & 0.4 & 4.3 & -0.2 & 1.7 & 0.1 & 1.6 & 0.1 & 6.7 & -24.3 \\
\hline
\end{tabular}

${ }^{1}$ Weighted averages, with weights assigned based on each country's share in the EU-27's GDP. 


\begin{tabular}{lcccccccccc}
\hline 1 & 2 & 3 & 4 & 5 & 6 & 7 & 8 & 9 & 10 & 11 \\
\hline LTU & 3.5 & 0.3 & 2.5 & 0.1 & 0.8 & 0.1 & 0.8 & 0.1 & 9.1 & -11.6 \\
MLT & 7.0 & 2.2 & 3.3 & 0.7 & 3.0 & 1.0 & 2.3 & 0.7 & 31.8 & -9.0 \\
POL & 4.2 & 0.9 & 1.9 & 0.7 & 1.2 & 0.2 & 1.0 & 0.2 & 21.2 & 12.2 \\
ROU & 4.3 & 0.5 & 2.8 & 0.1 & 0.8 & 0.1 & 0.7 & 0.1 & 12.2 & -12.6 \\
SVK & 5.2 & 0.8 & 2.7 & -0.1 & 2.1 & 0.3 & 1.9 & 0.3 & 15.8 & -19.4 \\
SVN & 7.2 & 1.0 & 1.9 & 0.2 & 3.5 & 0.5 & 2.4 & 0.3 & 14.3 & -0.2 \\
\hline EU-15* & 8.8 & 1.2 & 2.4 & 0.6 & 7.1 & 1.1 & 4.2 & 0.8 & 12.9 & 3.3 \\
EU-12* & 5.2 & 1.0 & 1.9 & 0.3 & 1.7 & 0.4 & 1.4 & 0.3 & 20.3 & -0.1 \\
\hline
\end{tabular}

${ }^{*}$ Change in the period 1995-2011.

"Weighted averages, with weights assigned based on each country's share in the EU-15's; and EU-12's GDP respectively (all values in current prices, US dollars).

Source: own calculations based on data derived from: the source as in Figure 1; National accounts... (2017).

In 2011, the highest KIBS intensity was recorded in Ireland (15.1\%) and Luxembourg (11\%).

KIBS intensities increased in almost all countries, and they generally reached higher values in countries with higher GDP per capita, i.e. in the EU-15 than the EU-12, as well as in the higher-income countries within both groups. A positive correlation between KIBS intensity and GDP per capita occurred with respect to both imported and domestic KIBS inputs, and it was stronger in the case of imported KIBS input (the Pearson's correlation coefficient achieved the values of 0.5 and 0.3 , respectively). The analysis based on KIBS input per capita shows even larger disparities between the more and less developed EU countries. Generally, it is not evident that a relatively low level of domestic KIBS intensity was compensated for by a relatively higher level of imported KIBS intensity. Excluding the cases of Ireland and Luxembourg, this is apparent only in Finland and Hungary. Bulgaria, followed by Lithuania, Poland and Romania, recorded the lowest domestic and imported KIBS intensity.

While taking into account a relative importance of imported KIBS, it was also usually higher in countries with higher incomes and the resulting higher KIBS intensities. The situation was different in the largest, high-income EU-15 countries, where relatively high total KIBS intensities were accompanied by the lowest shares of imported KIBS input in total KIBS input. The average importance of KIBS imports was significantly higher for EU-12 than EU-15. One should note, however, that the EU-15's weighted average is underestimated because of very low shares in the largest EU countries, whereas in this group there are also a few smaller economies with the highest reliance on KIBS imports (Ireland, Luxembourg, Netherlands, Finland). Thus, in reality the disparities between these two groups are less significant. In the EU-12 the relationship between market size and the role of imported KIBS was less apparent than in the EU-15.

Most of the EU-12 countries experienced a decrease in the share of imported KIBS input in total KIBS input, with the most significant drop in Latvia and Slovakia. In the EU-15 the trend was generally reversed, and the strongest increase, much higher than in other countries, took place in Ireland (21 pp). A relatively high growth is also visible in Luxembourg (13.8 pp), Greece (7.7 pp) and Spain (6.6 pp), as well as in Poland (12.2 pp). In 2011 the share of imported KIBS input in total KIBS input ranged from $38 \%$ in the Netherlands to $6 \%$ in Germany. Ireland and Luxembourg clearly stood out among the EU countries, as imported KIBS input was higher than the domestic one, with a high upward trend - as a result in 2011 in Ireland 76\% of KIBS input and in Luxembourg 61\% came from import (in general, these two countries were distinguished by a relatively high importance of imported service input). 
The values of indicators presented in Tables 1 and 2 show that the countries with a relatively high importance of imported KIBS usually also enjoyed a relatively high importance of KIBS exports (the Pearson's correlation coefficient for imported KIBS input per capita and KIBS exports per capita amounted to 0.8), and the highest values of KIBS exports per capita, much higher than in other countries, were achieved by Ireland and Luxembourg. KIBS exports played a more important role in the EU-15 than the EU-12, and the disparities between them tend to increase. One should note, however, that in most cases a large part of KIBS trade was carried out by FCEs, e.g. in Ireland they accounted for $61 \%$ of KIBS exports and $56 \%$ of KIBS imports. The importance of FCEs in KIBS trade was significantly higher in the EU-12 than the EU-15, with their highest share in Romania.

Table 2. KIBS exports and imports

\begin{tabular}{|c|c|c|c|c|c|c|}
\hline \multirow[b]{2}{*}{ Country } & \multicolumn{2}{|c|}{ KIBS exports/total exports } & \multicolumn{2}{|c|}{$\begin{array}{l}\text { KIBS exports per capita } \\
\text { (mln of US\$) }\end{array}$} & $\begin{array}{l}\text { KIBS exports by } \\
\text { FCEs }\end{array}$ & $\begin{array}{l}\text { KIBS imports by } \\
\text { FCEs }\end{array}$ \\
\hline & $\begin{array}{c}2011 \\
(\%)\end{array}$ & $\begin{array}{l}1995-2011^{* *} \\
(p p)\end{array}$ & 2011 & $1995-2011^{* *}$ & & \\
\hline AUT & 6.6 & -2.2 & 1.7 & 0.9 & 6.4 & 14.0 \\
\hline BEL & 8.0 & 2.9 & 2.7 & 1.8 & 19.2 & 18.3 \\
\hline DNK & 5.1 & 3.1 & 1.5 & 1.2 & 25.6 & 66.9 \\
\hline FIN & 9.4 & 4.9 & 1.8 & 1.4 & 20.6 & 62.4 \\
\hline FRA & 5.9 & 1.0 & 0.6 & 0.4 & 25.7 & 28.1 \\
\hline DEU & 3.9 & 1.4 & 0.8 & 0.6 & 22.5 & 24.1 \\
\hline GBR & 12.1 & 5.3 & 1.3 & 1.0 & 30.1 & 49.3 \\
\hline GRC & 3.7 & 1.8 & 0.1 & 0.1 & 0.0 & 0.0 \\
\hline IRL & 17.1 & 12.9 & 8.0 & 7.4 & 60.5 & 55.9 \\
\hline ITA & 4.0 & 1.3 & 0.4 & 0.3 & 24.2 & 38.9 \\
\hline LUX & 6.2 & 3.0 & 10.9 & 9.3 & - & - \\
\hline NLD & 9.3 & 2.5 & 3.0 & 2.0 & 48.5 & 42.6 \\
\hline PRT & 4.8 & 2.1 & 0.3 & 0.2 & 4.5 & 32.8 \\
\hline ESP & 8.2 & 4.3 & 0.7 & 0.6 & - & - \\
\hline SWE & 10.8 & 5.6 & 2.8 & 2.3 & 36.3 & - \\
\hline BGR & 0.9 & 0.4 & 0.03 & 0.03 & 48.8 & 74.4 \\
\hline CYP & 3.6 & 1.6 & 0.2 & 0.2 & - & - \\
\hline CZE & 3.5 & -2.7 & 0.6 & 0.4 & - & 0.1 \\
\hline EST & 6.2 & 3.0 & 0.5 & 0.5 & 21.4 & 48.3 \\
\hline HUN & 4.9 & -1.7 & 0.6 & 0.5 & 39.4 & 49.0 \\
\hline LVA & 3.5 & -1.7 & 0.2 & 0.1 & 36.6 & 35.5 \\
\hline LTU & 1.6 & 0.3 & 0.1 & 0.1 & 12.7 & 57.6 \\
\hline MLT & 9.6 & 5.3 & 1.3 & 1.0 & 4.7 & 14.2 \\
\hline POL & 3.4 & 2.5 & 0.2 & 0.2 & 42.0 & 54.8 \\
\hline ROU & 6.6 & 3.8 & 0.2 & 0.2 & 89.1 & 64.3 \\
\hline SVK & 3.3 & -0.5 & 0.4 & 0.3 & 49.7 & 55.2 \\
\hline SVN & 3.2 & 0.8 & 0.4 & 0.3 & - & - \\
\hline EU-15"* & 6.9 & 2.7 & 1.2 & 0.9 & $26.0^{4+* t+}$ & 34.1 \\
\hline EU-12 & 3.9 & 0.9 & 0.3 & 0.3 & $48.5^{*+* *+*}$ & 46.4 \\
\hline
\end{tabular}

' KIBS exports/KIBS imports by FCEs as \% total KIBS exports/total KIBS imports. KIBS defined as comprising 'Professional, scientific and technical activities', and 'Information and communication'.

" Change in the period 1995-2011.

"weighted averages, with weights assigned based on each country's share in the EU-15's; and EU-12's GDP respectively (all values in current prices, US dollars).

**** EU-13 (without LUX and ESP), EU-9 (without CYP, CZE and SVN).

Source: own calculations based on data derived from: the source as in Table 1; and Trade... (2017). 


\section{Conclusions}

Based on the study carried out in this paper a few conclusions can be formulated:

1. The EU-12 appeared to be more dependent on KIBS imports, which is in line with the lower-income countries' poorer endowment in knowledge. The EU-15's reliance on KIBS imports was determined by market size, whereas in the EU-12 this tendency was less obvious. As far as KIBS intensity is concerned (both domestic and imported), it was positively correlated with the level of economic development. A relatively higher importance of imported KIBS was usually accompanied by a relatively higher importance of KIBS exports, in large part attributed to FCEs. The EU-12 countries decreased their reliance on KIBS imports (in a result of their rapid economic and service sectors' development), whereas in the EU-15 the trend was reversed.

2. In most countries, KIBS were mainly delivered by companies operating on domestic markets. The growing role of import in providing KIBS is visible (the growth was a bit higher than with respect to total services), but this tendency was rather weak when compared with the growing importance of manufacturing intermediate import. This leads to the conclusion that there is still a need for direct proximity between service providers and customers in delivering most services, including KIBS.

3. Ireland and Luxembourg stood out among the EU countries with their highest KIBS intensities and growth of KIBS import, as well as the domination of imported over domestic KIBS inputs, accompanied by the highest and rapidly growing importance of KIBS exports. Both countries are attractive locations for transnational corporations, which are involved in numerous business relationships with their subsidiaries, co-operatives and customers located throughout the world, which in turn stimulates KIBS trade in these countries. ${ }^{2}$

4. The findings of the study are subject to some limitations. First, the studies on international trade in intermediates should be based on data from input-output tables, and the creation of the WIOD databases gave such an opportunity. One should note, however, that the WIOD 2013 Release is based on NACE Rev. 1.1 and covers a limited period. Its new release is under construction now, and it may open up some new opportunities for continuing research in this field based on NACE Rev. 2 and over a longer period of time. Second, KIBS input is embodied in the values of other products being traded internationally, and thus the calculation of KIBS content in international trade should be the subject of a separate study. Third, while analyzing KIBS trade, data on global sourcing are required, as its large part is carried out by transnational corporations, which hides a real export potential and import needs of different countries. Therefore, it is recommended that international organizations (e.g. Eurostat, WTO) should undertake some actions aimed at collecting the data on global sourcing of services.

2 Luxembourg is recognized as a tax haven, and characterized by very favorable regulations, political stability, financial security and its location in the center of Europe (Mainelli, Yeandle, 2009). Ireland is not officially recognized as a tax heaven, but it has the features of a tax heaven and provides prolific tax loopholes for many large service multinationals (Stewart, 2014), as well as it is an English-speaking country. 


\section{Referencess}

Baldwin, R.E. (2006). Globalisation: The Great Unbundling(s). Retrieved from: http://appli8.hec.fr/map/files/globalisationthegreatunbu ndling(s).pdf (20.01.2017).

Baldwin, R.E. (2014). Trade and Industrialisation after Globalisation's Second Unbundling: How Building and Joining a Supply Chain are Different and Why it Matters. In: R.C. Feenstra, A.M. Taylor (eds.), Globalization in an Age of Crisis: Multilateral Economic Cooperation in the Twenty first Century (pp. 165-212). Chicago, IL: University of Chicago Press/NBER.

Baldwin, R.E., Lopez-Gonzalez, J. (2015). Supply-chain Trade: A Portrait of Global Patterns and Several Testable Hypotheses. The World Economy, 11 (38), 1682-1721.

Bhagwati, J.N. (1984). Splintering and disembodiment of services and developing nations. The World Economy, 1 (7), 133-143.

Falk, M., Peng, F. (2011). The increasing service intensity of European manufacturing. MPRA Paper, 3860. Retrieved from: http://mpra. ub.uni-muenchen.de/38600 (22.01.2017).

Fixler, D., Siegel, D. (1999). Outsourcing and productivity growth in services. Structural Change and Economic Dynamics, 2 (10), 177-194.

Jones, R.W., Kierzkowski, H. (1990). The role of services in production and international trade: a theoretical framework. In: R.W. Jones, A. Krueger (eds.), The Political Economy of International Trade (pp. 31-48). Oxford: Basil Blackwell.

Lewin, A.Y., Massini, S., Peeters C. (2009). Why Are Companies Offshoring Innovation? The Emerging Gobal Race for Talent. Journal of International Business Studies, 6 (40), 901-925.

Mainelli, M., Yeandle, M. (2009). The Global Financial Centres Index. Retrieved from: http://www.zyen.com/PDF/GFCl_1_March_2007. $\operatorname{pdf}(5.06 .2016)$.

Miroudot, S., Lanz, R., Ragoussis, A. (2009). Trade in Intermediate Goods and Services. OECD Trade Policy Papers, 93. Retrieved from: http://dx.doi.org/10.1787/5kmlcxtdlk8r-en (5.11.2017).

Motohashi, K. (1997). ICT diffusion and its economic impact in OECD countries. OECD Science Technology and Industry Review, 20, 13-45.

National accounts (including GDP) (2017). Retrieved from: http:/lec.europa.eu/eurostat/data/browse-statistics-by-theme (2.11.2017).

National Input-Output Tables (2013). Retrieved from: http://www.wiod.org/release13 (7.04.2015).

Rybiński, K. (2008). Outsourcing i offshoring usług. Siatka pojęć, trendy i bariery rozwojowe. In: A. Szymaniak (ed.), Globalizacja usług. Outsourcing, offshoring i shared services centres (pp. 169-188). Warszawa: Wydawnictwa Akademickie i Profesjonalne.

Stewart, J. (2014). PwC/World Bank Report 'Paying Taxes 2014': An Assessment. IIIS Discussion Paper, 442. Retrieved from: https:/l www.tcd.ie/iiis/publications/discussion-papers.php (5.06.2016).

Trade by Enterprise Characteristics (2017). Retrieved from: http://www.oecd.org/std/its/trade-by-enterprise-characteristics.htm (2.11.2017).

Wyszkowska-Kuna, J. (2016). Usługi biznesowe oparte na wiedzy. Wpływ na konkurencyjność gospodarki na przykładzie wybranych krajów Unii Europejskiej. Łódź: Wydawnictwo Uniwersytetu Łódzkiego.

Wyszkowska-Kuna J. (2017). The role of intermediate demand and technology for international competitiveness of the KIBS sector: Evidence from European Union countries. The Journal of International Trade \& Economic Development, 7 (26), 777-800.

Cite this article aS: Wyszkowska-Kuna, J. (2018). The role of import for KIBS intensity: A comparative analysis of European Union countries. European Journal of Service Management, 2 (26), 329-336. DOI: 10.18276/ejsm.2018.26-41. 